\title{
Laboratory Model 50 kW Hall Thruster
}

David Manzella

University of Toledo, Toledo, Ohio

Robert Jankovsky

Glenn Research Center, Cleveland, Ohio

Richard Hofer

QSS Group, Inc., Cleveland, Ohio 
Since its founding, NASA has been dedicated to the advancement of aeronautics and space science. The NASA Scientific and Technical Information (STI) Program Office plays a key part in helping NASA maintain this important role.

The NASA STI Program Office is operated by Langley Research Center, the Lead Center for NASA's scientific and technical information. The NASA STI Program Office provides access to the NASA STI Database, the largest collection of aeronautical and space science STI in the world. The Program Office is also NASA's institutional mechanism for disseminating the results of its research and development activities. These results are published by NASA in the NASA STI Report Series, which includes the following report types:

- TECHNICAL PUBLICATION. Reports of completed research or a major significant phase of research that present the results of NASA programs and include extensive data or theoretical analysis. Includes compilations of significant scientific and technical data and information deemed to be of continuing reference value. NASA's counterpart of peerreviewed formal professional papers but has less stringent limitations on manuscript length and extent of graphic presentations.

- TECHNICAL MEMORANDUM. Scientific and technical findings that are preliminary or of specialized interest, e.g., quick release reports, working papers, and bibliographies that contain minimal annotation. Does not contain extensive analysis.

- CONTRACTOR REPORT. Scientific and technical findings by NASA-sponsored contractors and grantees.
- CONFERENCE PUBLICATION. Collected papers from scientific and technical conferences, symposia, seminars, or other meetings sponsored or cosponsored by NASA.

- SPECIAL PUBLICATION. Scientific, technical, or historical information from NASA programs, projects, and missions, often concerned with subjects having substantial public interest.

- TECHNICAL TRANSLATION. Englishlanguage translations of foreign scientific and technical material pertinent to NASA's mission.

Specialized services that complement the STI Program Office's diverse offerings include creating custom thesauri, building customized databases, organizing and publishing research results ... even providing videos.

For more information about the NASA STI Program Office, see the following:

- Access the NASA STI Program Home Page at $h t t p: / / w w w . s t i . n a s a . g o v$

- E-mail your question via the Internet to help@sti.nasa.gov

- Fax your question to the NASA Access Help Desk at 301-621-0134

- Telephone the NASA Access Help Desk at 301-621-0390

- Write to:

NASA Access Help Desk

NASA Center for AeroSpace Information 7121 Standard Drive

Hanover, MD 21076 


\section{Laboratory Model 50 kW Hall Thruster}

David Manzella

University of Toledo, Toledo, Ohio

Robert Jankovsky

Glenn Research Center, Cleveland, Ohio

Richard Hofer

QSS Group, Inc., Cleveland, Ohio

Prepared for the

38th Joint Propulsion Conference and Exhibit

cosponsored by the AIAA, ASME, SAE, and ASEE

Indianapolis, Indiana, July 7-10, 2002

National Aeronautics and

Space Administration

Glenn Research Center 
Available from

NASA Center for Aerospace Information 7121 Standard Drive

Hanover, MD 21076
National Technical Information Service 5285 Port Royal Road Springfield, VA 22100

Available electronically at http://gltrs.grc.nasa.gov 


\title{
Laboratory Model 50 kW Hall Thruster
}

\author{
David Manzella \\ University of Toledo \\ Toledo, Ohio 43606 \\ Robert Jankovsky \\ NASA Glenn Research Center \\ Cleveland, Ohio 44135 \\ Richard Hofer \\ QSS Group, Inc. \\ Cleveland, Ohio 44135
}

\begin{abstract}
A 0.46 meter diameter Hall thruster was fabricated and performance tested at powers up to 72 kilowatts. Thrusts up to 2.9 Newtons were measured. Discharge specific impulses ranged from 1750 to 3250 seconds with discharge efficiencies between 46 and 65 percent. Overall specific impulses ranged from 1550 to 3050 seconds with overall efficiencies between 40 and 57 percent. Performance data indicated significant fraction of multiple-charged ions during operation at elevated power levels. Cathode mass flow rate was shown to be a significant parameter with regard to thruster efficiency.
\end{abstract}

\section{Introduction}

High power electric propulsion systems have been shown to enable a number of missions including missions to Mars and Earth orbital solar electric power generation for terrestrial use. ${ }^{1,2}$ These types of missions require moderate transfer times and sizable thrust levels resulting in an optimized propulsion system specific impulse from 2000-3000 seconds based on the available on-board power. Hall thruster technology offers a favorable combination of performance, reliability, and lifetime for such applications based on the characteristics of state-ofthe-art systems. As a result, the NASA Space Solar Power Concept and Technology Maturation Program initiated preliminary strategic technology research and development into high power Hall thruster technology to enable space solar power systems and other high power spacecraft.

High power Hall thruster technology for primary propulsion applications was initially investigated in the former Soviet Union and later Russia for interplanetary missions. ${ }^{3,4}$ Efforts conducted at the FAKEL Design Bureau in Kaliningrad, Russia culminated in the SPT-290. This thruster utilized a $290 \mathrm{~mm}$ outer diameter ceramic channel to ultimately produce as much as 1.1 Newtons of thrust at 25 kilowatts of input power using xenon as the propellant. Efforts at the Central Scientific Institute for Machine Building (TsNIIMASH) in Korolev, Russia resulted in the demonstration of a 100 kilowatt two-stage anode layer thruster demonstrating a specific impulse of 8000 seconds with a discharge efficiency of 80 percent using bismuth as the propellant. Later a xenon fueled anode layer thruster was tested at power levels up to 25 kilowatts demonstrating performance similar to the SPT-290 at that power level. ${ }^{5}$ More recently an SPT-type thruster designated the T-220, which was developed in the United States under contract to NASA Glenn Research Center by TRW in cooperation with Space Power Incorporated (who has since become a part of Pratt \& Whitney's Space Propulsion and Chemical Systems Division), was tested. ${ }^{6}$ This thruster which has a $220 \mathrm{~mm}$ outer diameter ceramic channel was originally designed to produce 0.5 Newtons of thrust at $10 \mathrm{~kW}$ but has been modified to produce in excess of 1 Newton of thrust at elevated power levels.?

Development of a Hall thruster capable of operating at 2000-3000 seconds at power levels of 50 kilowatts and above requires a thruster design which preserves the physical processes required for efficient ionization and acceleration of the propellant. Important characteristics for preservation of these processes include: discharge current density, discharge chamber geometry, and magnetic field distribution. ${ }^{8}$ This paper describes the development of a Hall thruster designed to operate at 50 kilowatts. Test results including the effect of discharge voltage, anode mass flow rate and cathode mass flow rate on thruster performance are included.

\section{Apparatus}

A photograph of the NASA-457M 50-kilowatt laboratory Hall thruster is shown in figure 1 . The 
thruster, which has a $457 \mathrm{~mm}$ outer diameter ceramic discharge chamber, injects xenon propellant into the rear of the channel through a series of holes located along the inner and outer walls of the annular metallic anode located at the rear of the channel. The cathode, which has been previously described, ${ }^{9}$ was located on the thruster centerline.

A magnetic field is established across the exit plane of the discharge chamber through the use of two concentric electromagnets. Each electromagnet can be independently powered. The electromagnets along with magnetic poles and screens form the magnetic circuit. The design of the magnetic circuit was optimized through the use of a commercial threedimensional magneto-static computer code, Magnet 6 by Infolytica. The field line topography employed in the NASA $457 \mathrm{M}$ is qualitatively similar to the plasma lens design of the NASA $173 \mathrm{M} .{ }^{10}$ Following fabrication of the thruster the results from the magnetic model were compared with magnetic intensities measured with a 3 -axis Gauss meter. The measured and calculated radial and axial components of the magnetic field are shown in figure 2. The channel depth normalized the axial distance and both the radial and axial magnetic field components were normalized by the maximum values respectively. The inner radial magnetic field strength was slightly higher than calculated which also affected the centerline radial field strength. This difference was attributed to uncertainty in the properties of the material used in this part of the magnetic circuit.

The thruster was tested in a cryogenically pumped cylindrical vacuum chamber measuring 5 meters in diameter by 20 meters in length. This facility, which has been described in detail previously, ${ }^{10}$ was modified for this test. A cylindrical test port measuring 2 meters in diameter by 2.5 meters in length was mounted along the major axis of the tank with a 2-meter isolation valve between the test port and the main volume of the tank. A photograph of the test facility is shown in figure 3 . The effective pumping speed of the test facility in this configuration was 700,000 liters per second. This was determined based on the xenon mass flow rate and the tank pressure measured behind the thruster. As a result, the highest background pressure was $2 \times 10^{-5}$ Torr at a xenon flow rate of just over 1 standard liter per minute (SLPM). This pressure is still below the maximum recommended value for performance testing of $5 \times 10^{-5}$ Torr. $^{11}$ A laboratory xenon feed system, required auxiliary power supplies, and a data acquisition system were located adjacent to the test port on an elevated deck platform that was also modified for these tests. The discharge power supply was a remotely located three phase commercially available unit with a rated output of 100 Amperes and 2000 Volts. An output filter consisting of a $21 \mathrm{mF}$ capacitor located between the anode and cathode was used. The thrust produced by the NASA-457M was measured using an inverted pendulum design thrust stand fabricated specifically for these tests. The thrust stand was designed based on a thrust stand used in previous evaluations of Hall effect thrusters. ${ }^{12,13}$ Conceptually the thrust balance was identical to the previous design except for modifications necessary to accommodate the increased mass and currents. The thrust stand can be seen beneath the thruster in the photograph in figure 4. Due to the large thermal mass of the NASA-457M thruster no attempts were made to establish complete thermal equilibrium prior to measuring performance data. The thruster was typically operated for approximately an hour to allow not only the thruster discharge chamber to warm up, but to also allow the thrust stand to equilibrate with the operating thruster. Following this warm up period performance data was taken. Thrust stand calibrations, conducted by applying a series of one hundred gram weights, were conducted before and after each series of test data.

\section{Results and Discussion}

The NASA-457M was tested over a range of input powers from 9 to 72 kilowatts by varying the anode mass flow rate from 15 to $93 \mathrm{mg} / \mathrm{s}$ and the discharge voltage from 300 to 650 Volts. All these data are presented in an appendix at the end of this paper. Over this range of operating conditions thruster operation was stable. Thrust is plotted as a function of discharge power for five different discharge voltages in figure 5 . For each voltage the maximum current corresponded to approximately 110 Amperes. This maximum resulted from the maximum current capacity of the discharge power supply. As can be seen from the figure, thrust varied linearly with discharge power for a given discharge voltage. At 650 Volts a thrust of 2.9 Newtons was measured at 111 Amperes. There was no evidence of thermal limitations at this power level although it was noted that the anode was glowing upon shutdown. While this has been observed with other thrusters operating at nominal operating conditions at shutdown, this was not observed at powers up to $50 \mathrm{~kW}$ with the NASA$457 \mathrm{M}$. Operation at voltages above 650 Volts was investigated but was not adequately characterized due to voltage isolation problems within the thruster. Modification of the isolation scheme is currently underway which should allow for operation up to at 1000 Volts for future testing.

The reduction in thrust with increasing voltage at a given power level was accompanied by a corresponding increase in specific impulse. This is 
shown in figure 6 where specific impulse is plotted versus discharge power. Discharge specific impulse ranged from approximately 1750 seconds to 3250 seconds. The overall thruster specific impulse including the cathode mass flow rate and magnet power ranged from 1550 seconds to 3050 seconds. While overall specific impulse and efficiency are reported, it should be noted that no attempts were made to optimize the laboratory model cathode or magnetic circuit for efficient operation. The discharge specific impulse at a given voltage compares favorably with other state-of-the-art thrusters. For example at 300 Volts an SPT- 100 has a discharge specific impulse of 1750 seconds $^{14}$ and the comparably sized high voltage SPT-1 thruster provided between 2250 and 2500 seconds at 500 Volts. ${ }^{15}$ The functional dependence of specific impulse with discharge voltage was considered in more detail by Hofer where experimental data were compared with various predicted values. ${ }^{16}$ These predictions suggest as discharge power increased above 20 kilowatts or the discharge current increased above 30 Amperes that the effect of multiple-charged ions becomes significant.

The variation of discharge current versus anode mass flow rate is shown in figure 7. The dependence is linear for anode mass flow rates below approximately $70 \mathrm{mg} / \mathrm{s}$. Above this mass flow rate the discharge current increased more rapidly with increasing anode mass flow rate. This increase in current at high anode mass flow rate was the result of either an increase in the electron or ion current contribution to the discharge current. The corresponding specific impulse and higher density within the channel suggest that this effect is due to additional ion current from multiple-charged ions.

The effect of multiple charged ions on specific impulse was previously considered when Hofer predicted 100 Amperes at $88.8 \mathrm{mg} / \mathrm{s}$ and 500 Volts with a 2768 second specific impulse for a multiplecharged plasma. For a singly charged plasma 100 Amperes at $101 \mathrm{mg} / \mathrm{s}$ and 500 Volts with a 2622 second specific impulse was predicted. The measured anode mass flow rate at 500 Volts and 100 Amperes was $86.4 \mathrm{mg} / \mathrm{s}$ at just less than 2750 seconds, which agrees favorably with the multiple-charged prediction. This prediction and other predicted values of specific impulse are shown in figure 8 versus discharge voltage for an anode mass flow rate of $86.4 \mathrm{mg} / \mathrm{s}$. Experimental data are also included.

During the course of this investigation the effect of cathode flow rate on thruster performance was also considered. Previously the sensitivity of cathode mass flow rate on thruster operation was considered in detail for a $4.5 \mathrm{~kW}$ Hall thruster. ${ }^{17}$ As was pointed out in this prior investigation, the coupling of the plasma produced in the hollow cathode with the plasma produced in the Hall thruster discharge channel is not fully understood and is more complicated than running a hollow cathode with a simple external anode due to the presence of magnetic fields. Figure 9 shows the cathode-toground voltage as a function of discharge current for three different cathode flow rates. As can be seen from the figure, for each cathode flow rate the cathode-to-ground voltage varied linearly with discharge current with the voltage becoming more negative with increasing current.

For comparison purposes, this cathode was tested independent of the Hall thruster with an external anode at a mass flow rate of $2 \mathrm{mg} / \mathrm{s} .{ }^{9}$ For currents between 50 and 100 Amperes the coupling voltage was between -10 and -13 volts. This suggests that the additional voltage required to couple the plasma from the cathode to the plasma from the Hall thruster was associated with electron transport across the applied magnetic field. As such, this additional voltage represents a thruster loss mechanism since a larger portion of the voltage applied between the cathode and anode is needed for cathode coupling leaving a smaller portion of the total applied voltage for ion acceleration.

The effect of large cathode-to-ground coupling voltages on thruster discharge efficiency is shown in figure 10. These data show that the smaller the cathode-to-ground voltage the higher the discharge efficiency (and overall efficiency as can be seen in the data tables). This substantiates the conclusion that large cathode-to-ground voltages were indicative of an energy loss mechanism associated with poor cathode coupling. The data also indicate a peak discharge efficiency of near 65 percent at around 500 Volts. The efficiency decreases with increasing voltage above this value. This is consistent with past investigations into high voltage Hall thruster operation. ${ }^{15,18}$

\section{Conclusions}

A $0.46 \mathrm{~m}$ outer diameter Hall thruster was fabricated and performance tested at powers up to 72 kilowatts. These tests demonstrated the efficacy of scaling Hall thrusters to high power suitable for a range of future missions. Thrusts up to nearly 3 Newtons were measured. Discharge specific impulses ranged from 1750 to 3250 seconds with discharge efficiencies between 46 and 65 percent. Overall specific impulses ranged from 1550 to 3050 seconds with overall efficiencies between 40 and 57 percent. 
Performance data suggested a significant fraction of multiple-charged ions during operation at elevated power levels. This conclusion was supported by previous performance predictions by Hofer and the functional dependence of discharge current with anode mass flow rate.

An investigation into the effect of cathode flow rate on thruster operation was conducted. Cathode mass flow rate was shown to be a significant parameter with regard to thruster efficiency. It was also demonstrated that the coupling voltage between the cathode and thruster anode was significantly different than that measured with the cathode operating to a planar external anode.

\section{References}

1. Gefert, L., Hack, K., and Kerslake, T., "Options for the Human Exploration of Mars Using Solar Electric Propulsion," 1999.

2. Oleson, S., "Advanced Propulsion for Space Solar Power Satellites," AIAA-99-2872, June 1999.

3. Loeb, H. and Popov, G., "Advanced Interplanetary Mission of the XXI Century Using Electric Propulsion," IEPC-95-04, Sept. 1995.

4. Garkusha, V., et al., "Electric Propulsion Activity in TsNIIMASH," IEPC-95-09, Sept. 1995.

5. Jacobson, D. and Jankovsky, R., "Performance Evaluation of a $50 \mathrm{~kW}$ Hall Thruster," AIAA99-0457, January 1999.

6. Jankovsky, R., McLean, C., and McVey, J., "Preliminary Evaluation of a $10 \mathrm{~kW}$ Hall Thruster," AIAA-99-0456, January 1999.

7. Britt, N., "Electric Propulsion Activities in U.S. Industry," AIAA-2002-3559, July 2002.

8. Arkhipov, B., et al., "Development and Investigation of Characteristics of Increased Power SPT Models," IEPC-93-222, Sept. 1993.
9. Carpenter, C. and Patterson, M., "High-Current Hollow Cathode Development," IEPC-01-274, October 2001.

10. Hofer, R. R., Peterson, P. Y., Gallimore, A. D., "A High Specific Impulse Two-Stage Hall Thruster with Plasma Lens Focusing," IEPC-01036, $27^{\text {th }}$ International Electric Propulsion Conference, Pasadena, CA, Oct 14-19, 2001.

10. Grisnik, S., and Parkes, J., "A Large High Vacuum, High Pumping Speed Space Simulation Chamber for Electric Propulsion," IEPC93-151, Sept. 1993.

11. Randolph, T. et al., "Facility Effects on Stationary Plasma Thruster Testing," IEPC-9393, Sept. 1993.

12. Sankovic, J.M., Haag, T.W., and Manzella, D.H., "Operating Characteristics of the Russian D-55 Thruster with Anode Layer," AIAA-94-3011, June 1994.

13. Sankovic, J.M., Haag, T.W., and Manzella, D.H., "Performance Evaluation of a $4.5 \mathrm{~kW}$ SPT Thruster, " IEPC-95-30, Sept. 1995.

14. Kim, V. et al., "Development and Characterization of Small SPT," AIAA-98-3335, July 1998.

15. Manzella, D., Jacobson, D., and Jankovsky, R., "High Voltage SPT Performance," AIAA-20013774, July 2001.

16. Hofer, R. and Jankovsky, R., “A Hall Thruster Performance Model Incorporating the Effects of a Multiply-Charged Plasma," AIAA-2001-3322, July 2001.

17. Tilley, D., de Grys, K., and Myers, R., "Hall Thruster-Cathode Coupling," AIAA-99-2865, June 1999.

18. Jacobson, D., Jankovsky, R., and Manzella, D., "High Voltage TAL Performance," AIAA2001-3777. 


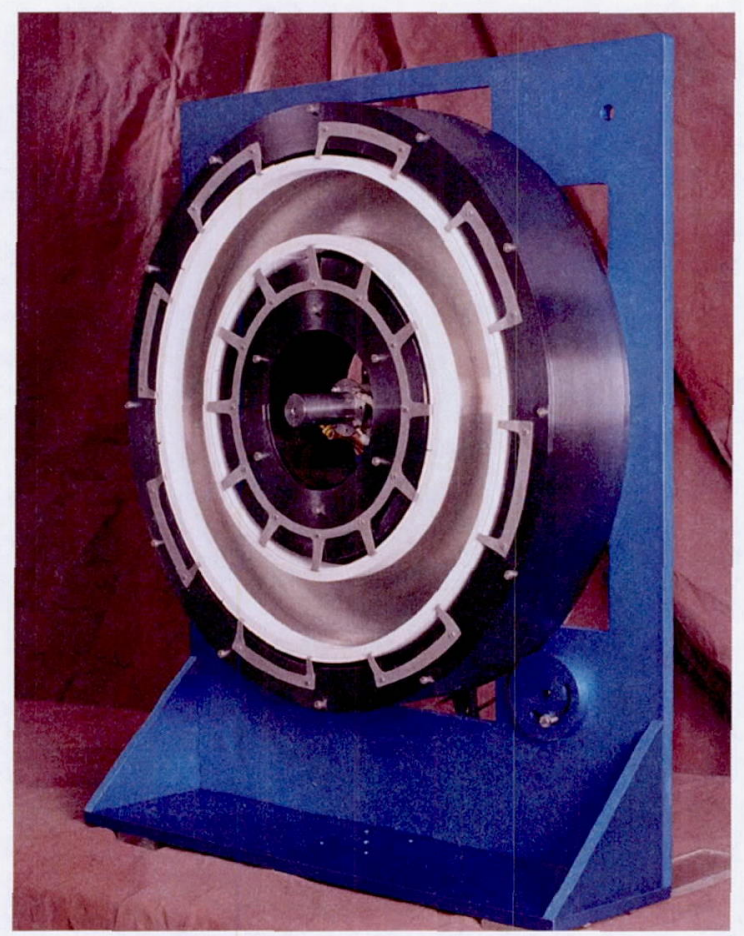

Figure 1: Photograph of the NASA-457M high power Hall thruster

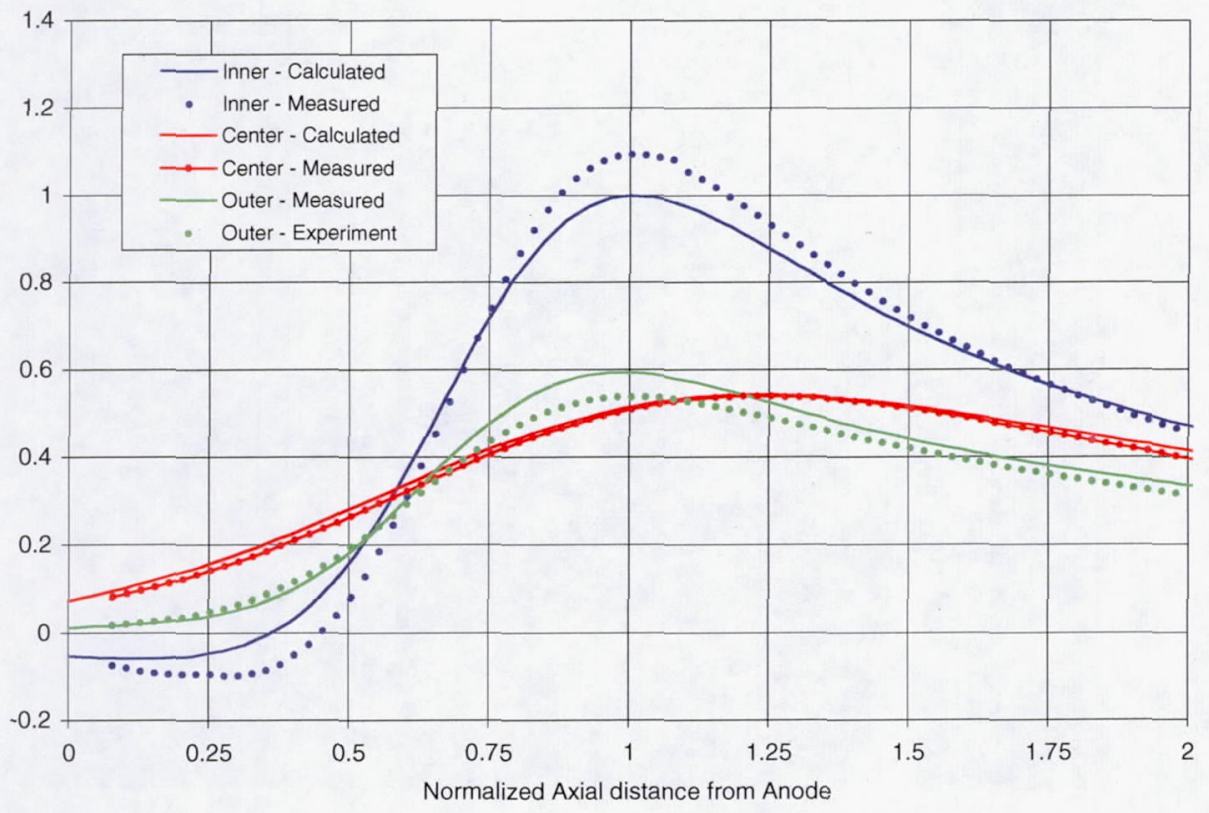

Figure 2a: Measured and predicted radial magnetic field strength 


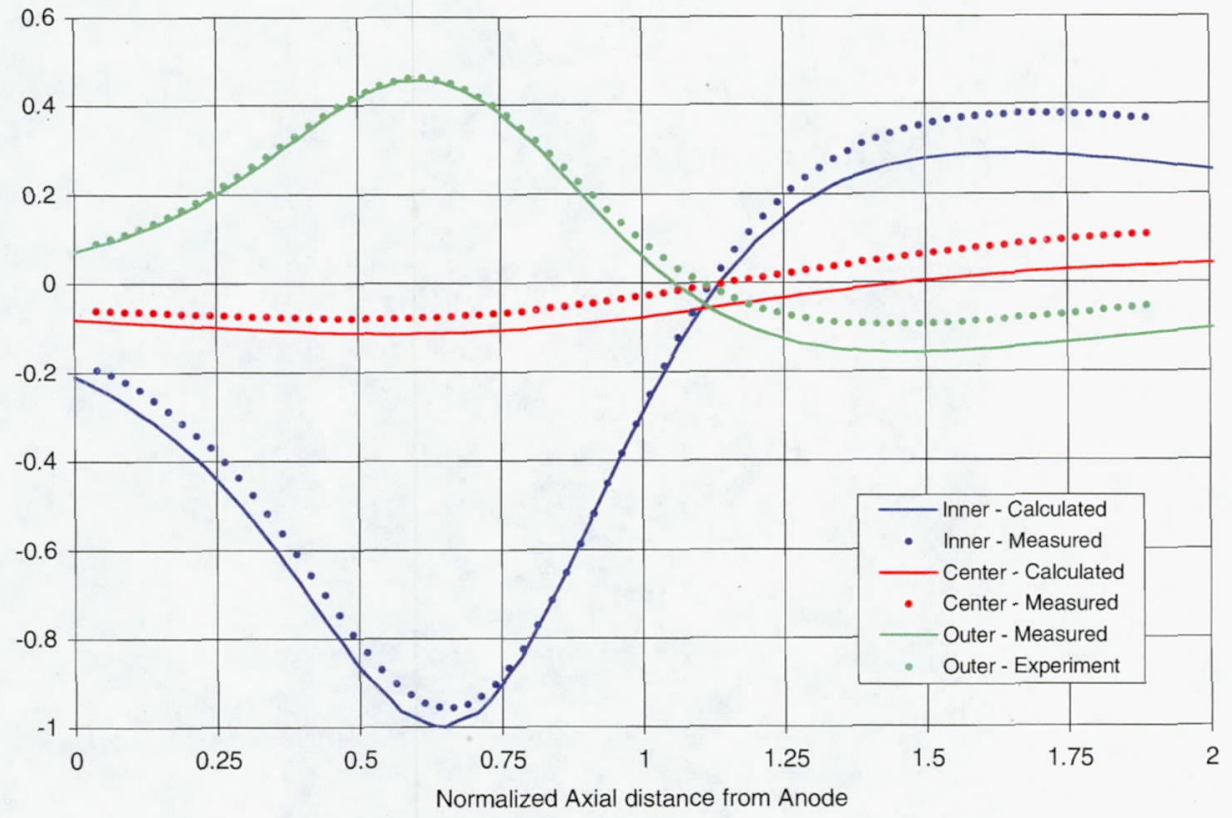

Figure 2b: Measured and predicted axial magnetic field strength

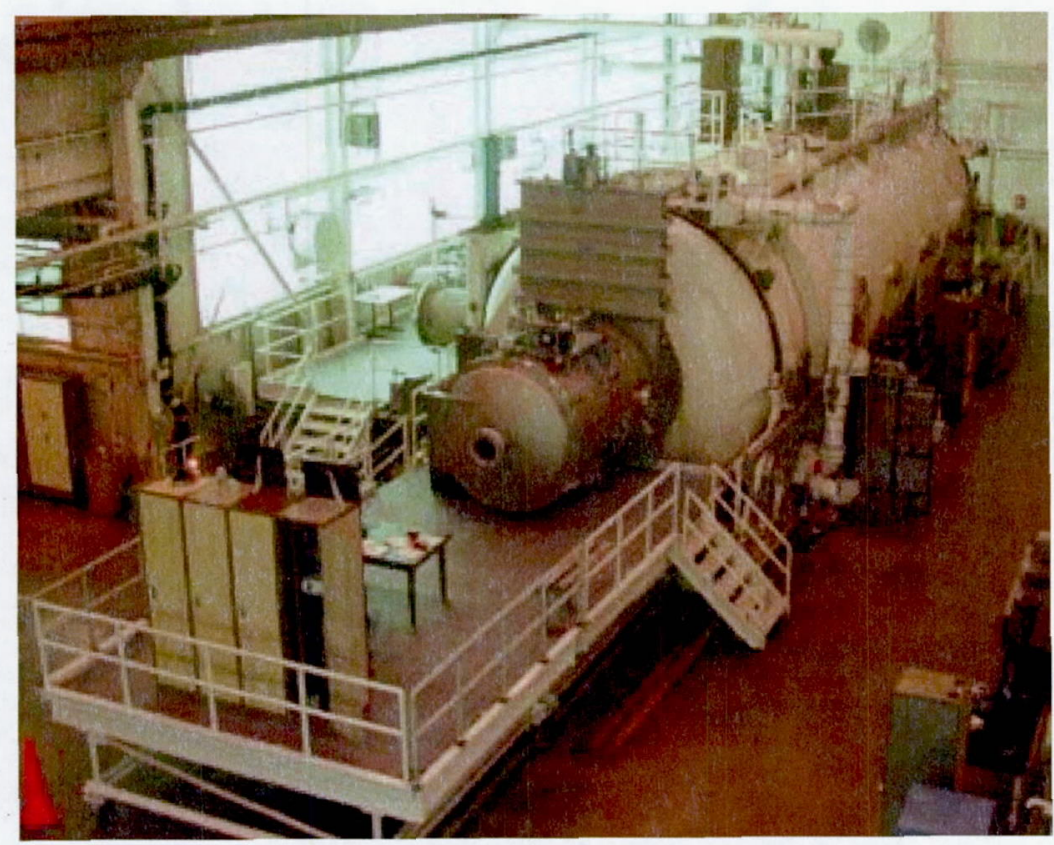

Figure3: Photograph test facility showing new test port. 


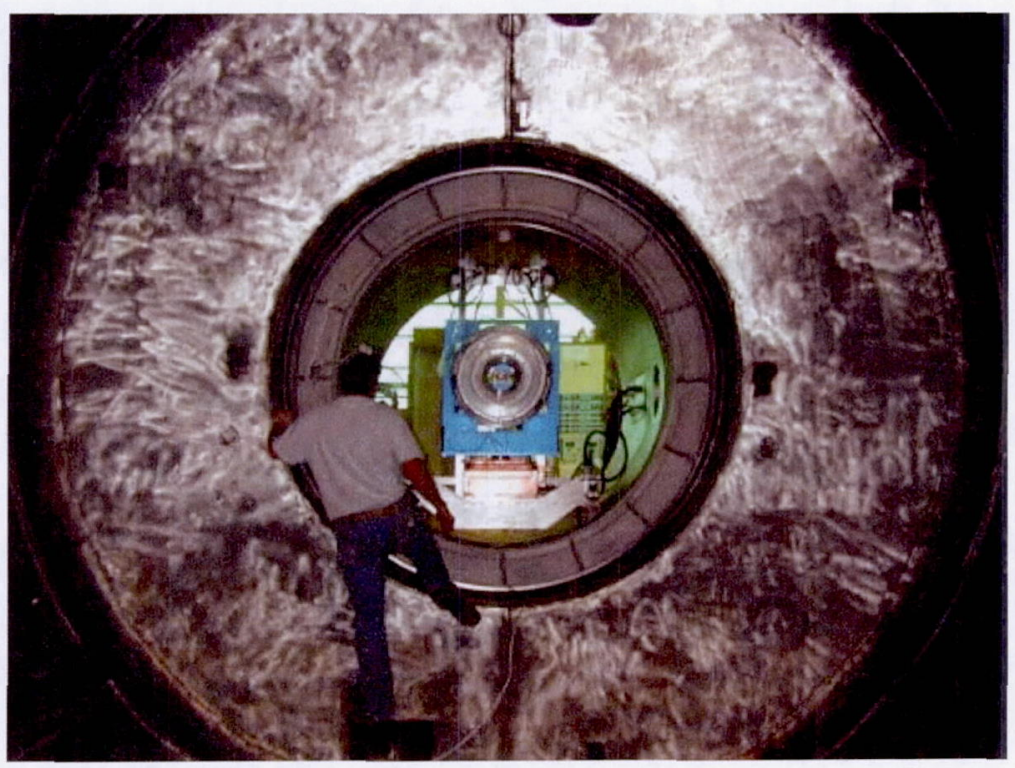

Figure 4: Photograph of thruster mounted on thrust stand in test port.

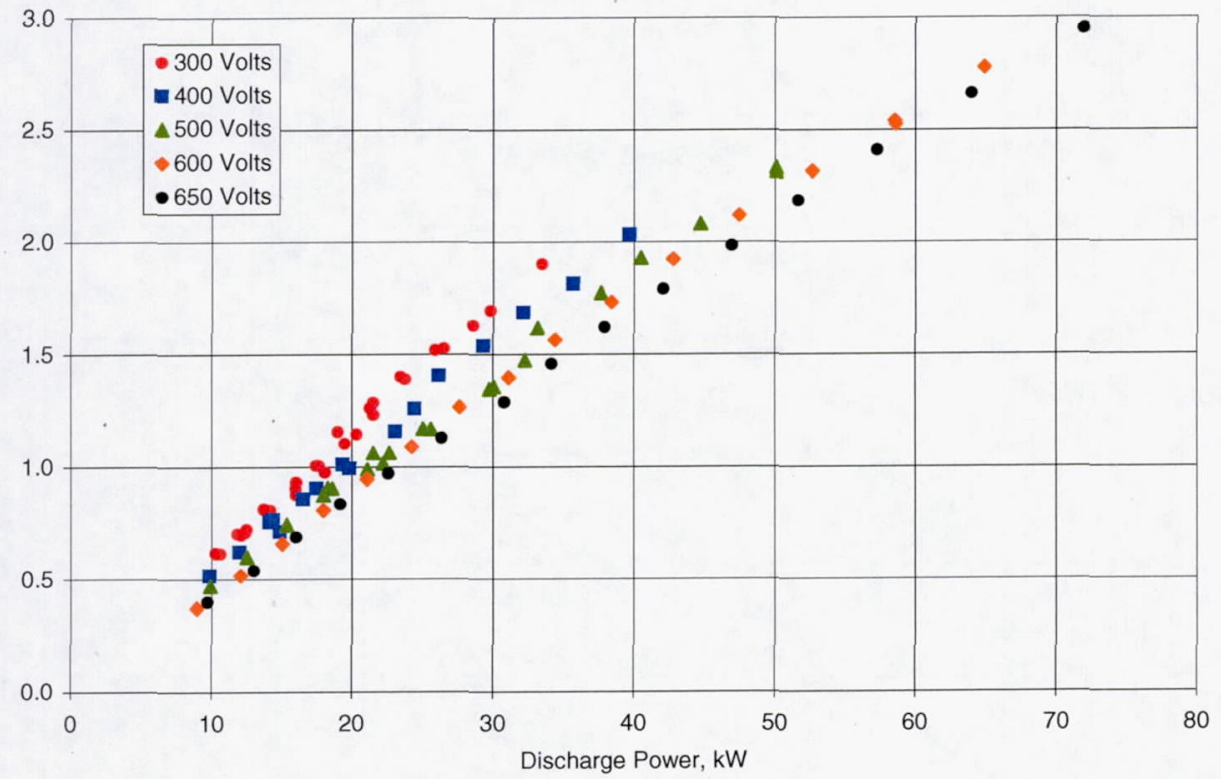

Figure 5: Thrust versus discharge power for various discharge voltages. 


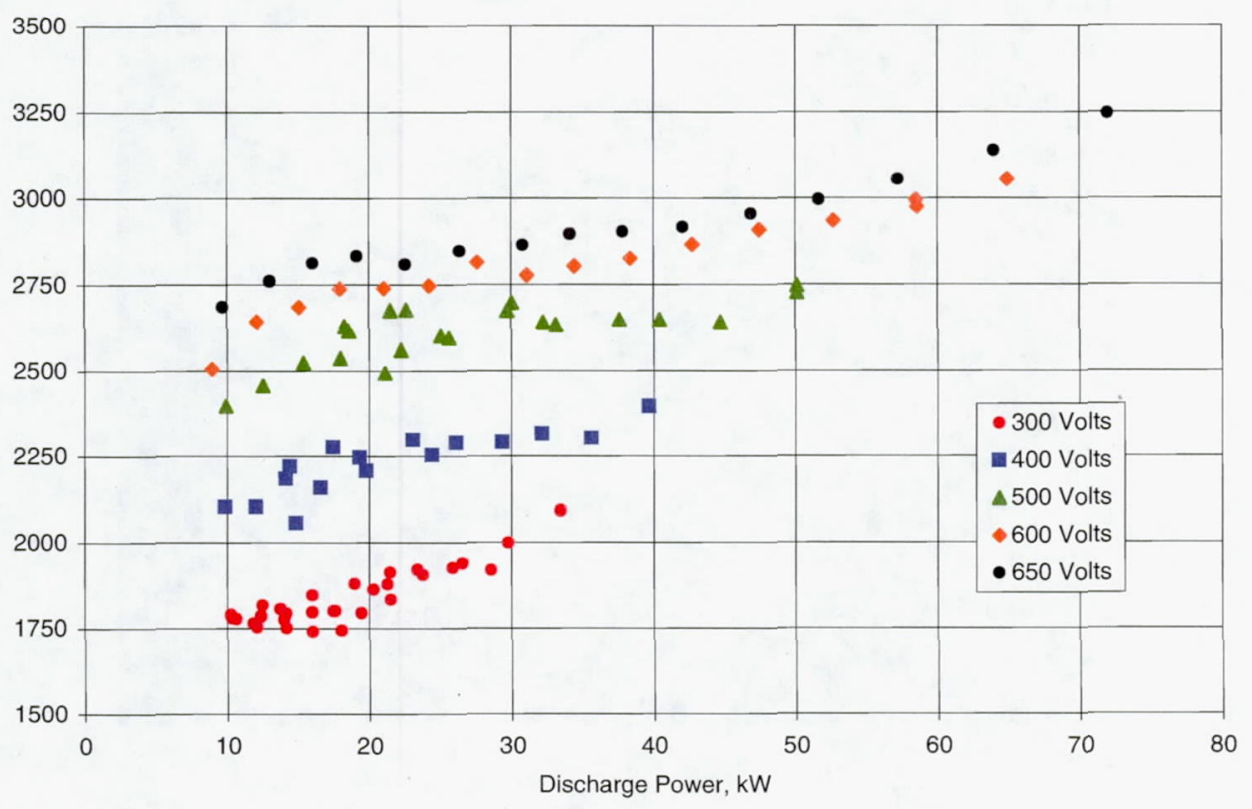

Figure 6: Discharge specific impulse versus discharge power for various discharge voltages.

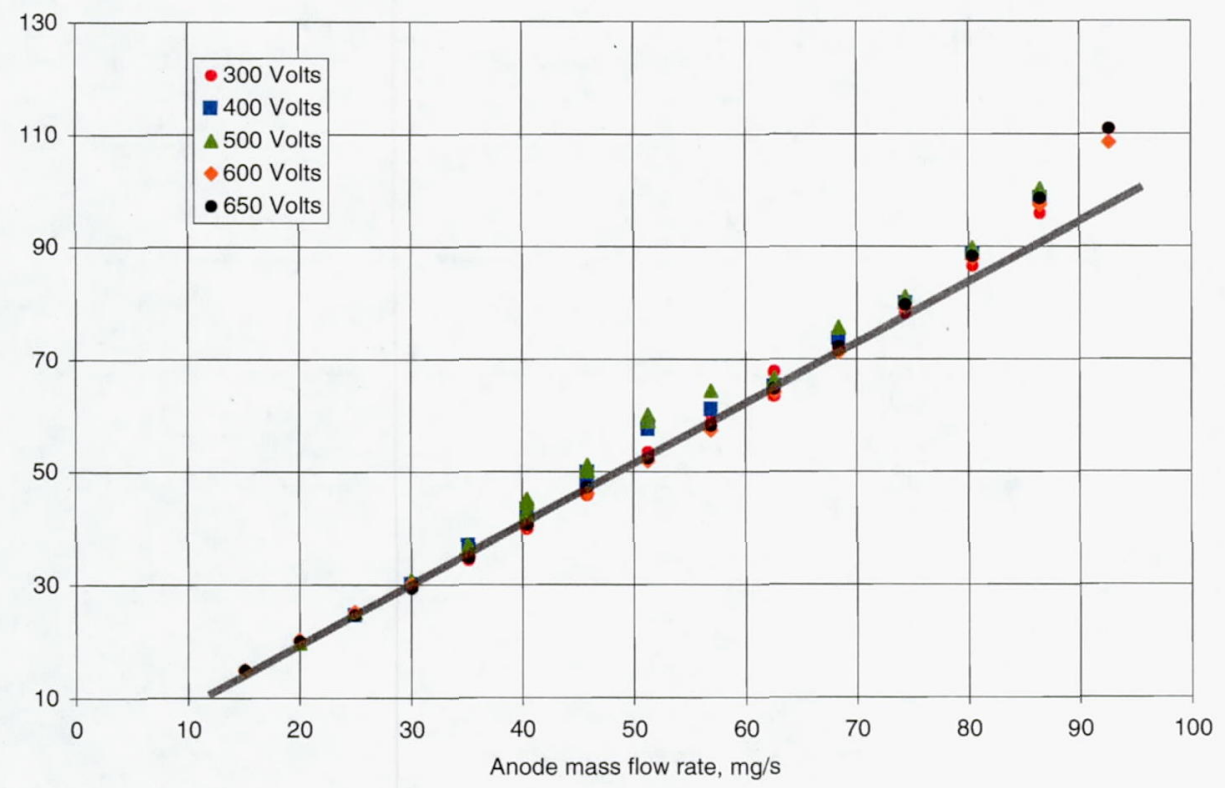

Figure 7: Discharge current versus anode mass flow rate for various discharge voltages. 


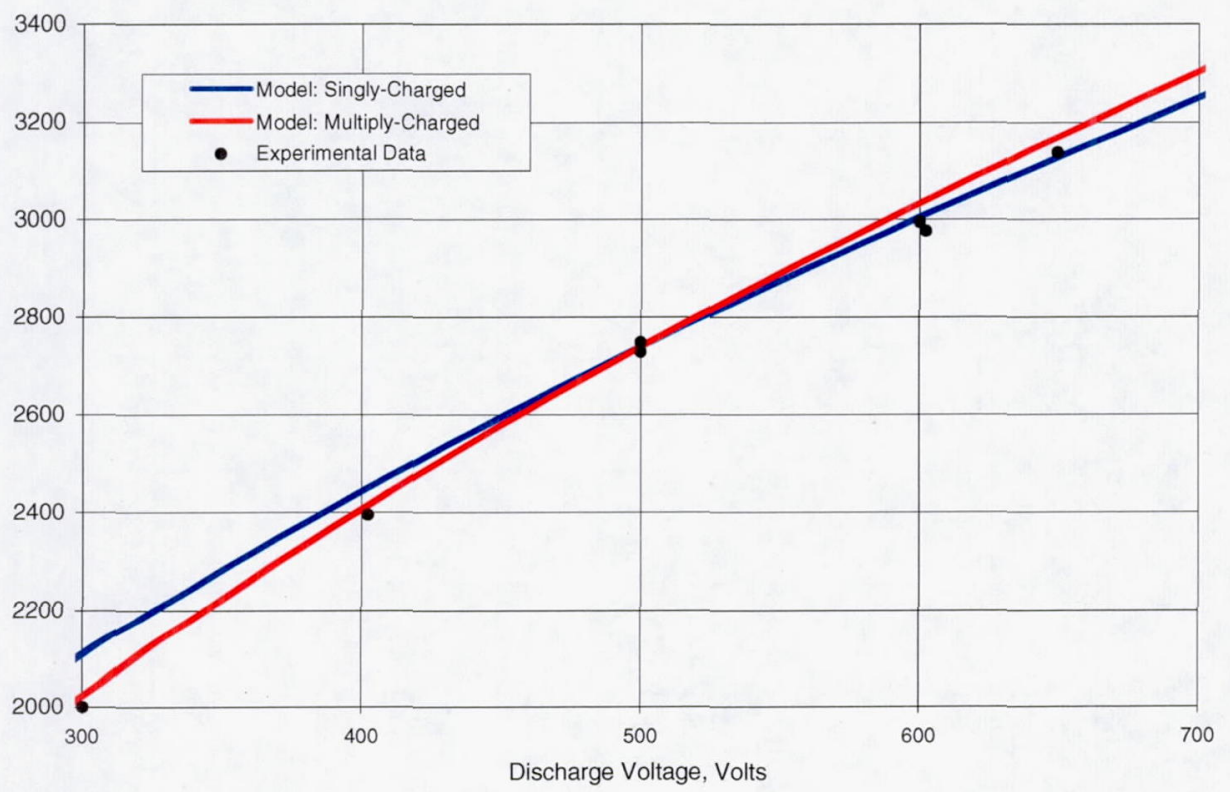

Figure 8: Predicted and measured specific impulse versus discharge voltage for an anode mass flow rate of $86.4 \mathrm{mg} / \mathrm{s}$.

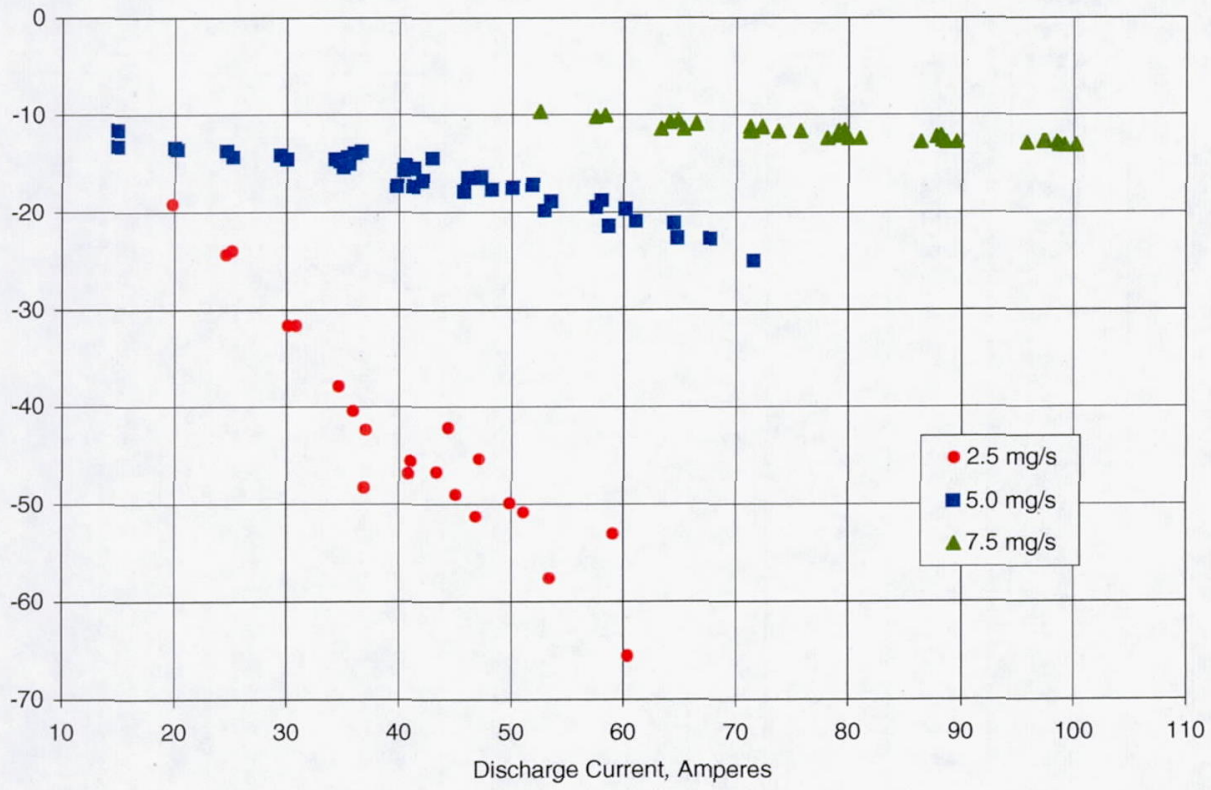

Figure 9: Cathode-to-ground voltage versus discharge current for various cathode flow rates. 


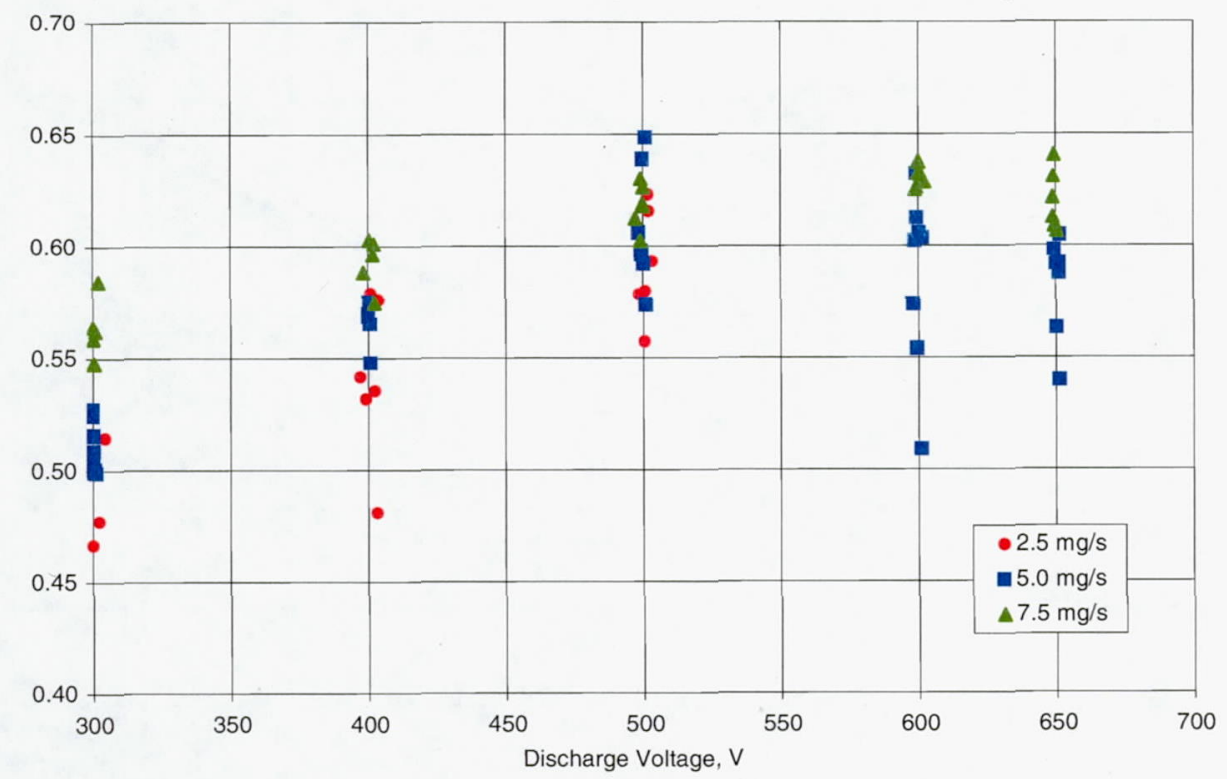

Figure 10: Discharge efficiency versus discharge current for various cathode flow rates.

Appendix: Data Table

\begin{tabular}{|c|c|c|c|c|c|c|c|c|c|c|c|}
\hline $\begin{array}{l}\text { Discharge } \\
\text { voltage, } \\
\text { Volts }\end{array}$ & $\begin{array}{l}\text { Discharge } \\
\text { current, } \\
\text { Amperes }\end{array}$ & $\begin{array}{c}\text { Discharge } \\
\text { power, } \\
\text { Watts }\end{array}$ & $\begin{array}{l}\text { Anode } \\
\text { mass } \\
\text { flow, } \\
\mathrm{mg} / \mathrm{s}\end{array}$ & $\begin{array}{c}\text { Cathode } \\
\text { mass } \\
\text { flow, } \\
\mathrm{mg} / \mathrm{s} \\
\end{array}$ & $\begin{array}{r}\text { Total } \\
\text { power, } \\
\text { Watts } \\
\end{array}$ & $\begin{array}{c}\text { Thrust, } \\
\mathrm{mN}\end{array}$ & \begin{tabular}{|c|} 
Total \\
specific \\
impulse, \\
seconds \\
\end{tabular} & $\begin{array}{c}\text { Discharge } \\
\text { specific } \\
\text { impulse, } \\
\text { seconds } \\
\end{array}$ & $\begin{array}{c}\text { Total } \\
\text { efficiency }\end{array}$ & $\begin{array}{l}\text { Discharge } \\
\text { efficiency }\end{array}$ & $\begin{array}{c}\text { Cathode-to-ground } \\
\text { voltage, } \\
\text { Volts }\end{array}$ \\
\hline 300 & 34 & 10287 & 35.2 & 5.0 & 11348 & 617 & 1567 & 1790 & 0.42 & 0.53 & -14.6 \\
\hline 300 & 35 & 10383 & 35.2 & 2.5 & 11483 & 614 & 1662 & 1781 & 0.44 & 0.52 & -37.9 \\
\hline 300 & 36 & 10661 & 35.2 & 5.0 & 11606 & 613 & 1557 & 1778 & 0.40 & 0.50 & -15.1 \\
\hline 299 & 40 & 11880 & 40.4 & 5.0 & 12961 & 701 & 1572 & 1766 & 0.42 & 0.51 & -17.3 \\
\hline 298 & 41 & 12150 & 40.4 & 2.5 & 13052 & 696 & 1653 & 1755 & 0.43 & 0.49 & -46.9 \\
\hline 304 & 41 & 12480 & 40.4 & 2.5 & 13735 & 721 & 1711 & 1817 & 0.44 & 0.51 & -45.6 \\
\hline 301 & 41 & 12411 & 40.4 & 5.0 & $\cdot 13385$ & 709 & 1590 & 1786 & 0.41 & 0.50 & -15.5 \\
\hline 300 & 46 & 13740 & 45.8 & 5.0 & 15010 & 812 & 1629 & 1807 & 0.43 & 0.52 & -17.9 \\
\hline 302 & 47 & 14183 & 45.8 & 2.5 & 15116 & 787 & 1661 & 1752 & 0.42 & 0.48 & -51.3 \\
\hline 298 & 47 & 14012 & 45.8 & 2.5 & 15015 & 798 & 1684 & 1776 & 0.44 & 0.50 & -45.4 \\
\hline 301 & 47 & 14168 & 45.8 & 5.0 & 15164 & 806 & 1617 & 1793 & 0.42 & 0.50 & -16.5 \\
\hline 301 & 53 & 15974 & 51.3 & 5.0 & 16999 & 904 & 1637 & 1796 & 0.43 & 0.50 & -19.9 \\
\hline 300 & 53 & 16031 & 51.3 & 2.5 & 16985 & 876 & 1660 & 1741 & 0.42 & 0.47 & -57.7 \\
\hline 299 & 54 & 16010 & 51.3 & 5.0 & 17358 & 930 & 1683 & 1847 & 0.44 & 0.53 & -18.9 \\
\hline 300 & 58 & 17453 & 56.9 & 5.0 & 18772 & 1005 & 1655 & 1801 & 0.43 & 0.51 & -18.8 \\
\hline 300 & 59 & 17622 & 56.9 & 5.0 & 18675 & 1005 & 1655 & 1801 & 0.44 & 0.50 & -21.5 \\
\hline 299 & 60 & 18078 & 56.9 & 2.5 & 19071 & 974 & 1671 & 1745 & 0.42 & 0.46 & -65.6 \\
\hline 300 & 63 & 18971 & 62.6 & 7.5 & 19643 & 1155 & 1679 & 1881 & 0.48 & 0.56 & -11.4 \\
\hline 300 & 65 & 19459 & 62.6 & 5.0 & 20542 & 1103 & 1663 & 1796 & 0.44 & 0.50 & -22.7 \\
\hline 300 & 68 & 20290 & 62.6 & 5.0 & 21664 & 1145 & 1726 & 1864 & 0.45 & 0.52 & -22.8 \\
\hline 299 & 71 & 21275 & 68.4 & 7.5 & 22400 & 1261 & 1694 & 1879 & 0.47 & 0.55 & -11.7 \\
\hline 301 & 71 & 21481 & 68.4 & 7.5 & 22829 & 1285 & 1726 & 1915 & 0.48 & 0.56 & -11.6 \\
\hline 300 & 72 & 21494 & 68.4 & 5.0 & 22596 & 1231 & 1710 & 1835 & 0.46 & 0.52 & -25 \\
\hline 300 & 78 & 23422 & 74.3 & 7.5 & 24701 & 1401 & 1746 & 1922 & 0.49 & 0.56 & -12.4 \\
\hline 300 & 79 & 23754 & 74.3 & 7.5 & 24901 & 1390 & 1732 & 1907 & 0.47 & 0.55 & -12.1 \\
\hline 300 & 86 & 25894 & 80.3 & 7.5 & 27194 & 1519 & 1763 & 1928 & 0.48 & 0.55 & -12.8 \\
\hline 301 & 88 & 26543 & 80.3 & 7.5 & 27707 & 1528 & 1774 & 1939 & 0.48 & 0.55 & -12.6 \\
\hline 298 & 96 & 28587 & 86.4 & 7.5 & 29923 & 1629 & 1767 & 1921 & 0.47 & 0.54 & -12.9 \\
\hline 300 & 99 & 29780 & 86.4 & 7.5 & 30970 & 1696 & 1840 & 2000 & 0.49 & 0.56 & -13.1 \\
\hline 302 & 111 & 33454 & 92.7 & 7.5 & 34663 & 1903 & 1937 & 2093 & 0.52 & 0.58 & -13.7 \\
\hline
\end{tabular}


Appendix: Data Table (concluded)

\begin{tabular}{|c|c|c|c|c|c|c|c|c|c|c|c|}
\hline $\begin{array}{c}\text { Discharge } \\
\text { voltage, } \\
\text { Volts }\end{array}$ & $\begin{array}{c}\text { Discharge } \\
\text { current, } \\
\text { Amperes }\end{array}$ & $\begin{array}{c}\text { Discharge } \\
\text { power, } \\
\text { Watts }\end{array}$ & $\begin{array}{l}\text { Anode } \\
\text { mass } \\
\text { flow, } \\
\mathrm{mg} / \mathrm{s} \\
\end{array}$ & $\begin{array}{c}\text { Cathode } \\
\text { mass } \\
\text { flow, } \\
\mathrm{mg} / \mathrm{s} \\
\end{array}$ & $\begin{array}{c}\text { Total } \\
\text { power, } \\
\text { Watts }\end{array}$ & \begin{tabular}{|c|} 
Thrust, \\
$\mathrm{mN}$
\end{tabular} & \begin{tabular}{c|} 
Total \\
specific \\
impulse, \\
seconds \\
\end{tabular} & $\begin{array}{c}\text { Discharge } \\
\text { specific } \\
\text { impulse, } \\
\text { seconds } \\
\end{array}$ & $\begin{array}{c}\text { Total } \\
\text { efficiency }\end{array}$ & $\begin{array}{l}\text { Discharge } \\
\text { efficiency }\end{array}$ & $\begin{array}{c}\text { Cathode-to-ground } \\
\text { voltage, } \\
\text { Volts }\end{array}$ \\
\hline 403 & 25 & 9904 & 24.9 & 2.5 & 10800 & 514 & 1911 & 2103 & 0.45 & 0.54 & -24.4 \\
\hline 399 & 30 & 12016 & 30.0 & 2.5 & 13084 & 619 & 1942 & 2104 & 0.45 & 0.53 & -31.7 \\
\hline 400 & 35 & 14164 & 35.2 & 5.0 & 15255 & 753 & 1912 & 2184 & 0.46 & 0.57 & -14.4 \\
\hline 401 & 36 & 14399 & 35.2 & 2.5 & 15556 & 766 & 2072 & 2220 & 0.50 & 0.58 & -40.5 \\
\hline 403 & 37 & 14885 & 35.2 & 2.5 & 16286 & 710 & 1921 & 2057 & 0.41 & 0.48 & -48.3 \\
\hline 401 & 41 & 16561 & 40.4 & 5.0 & 17747 & 857 & 1922 & 2160 & 0.46 & 0.55 & -17.4 \\
\hline 404 & 43 & 17485 & 40.4 & 2.5 & 18762 & 903 & 2143 & 2276 & 0.51 & 0.58 & -46.8 \\
\hline 401 & 48 & 19349 & 45.8 & 5.0 & 20643 & 1010 & 2025 & 2247 & 0.49 & 0.58 & -17.7 \\
\hline 397 & 50 & 19815 & 45.8 & 2.5 & 21055 & 992 & 2093 & 2207 & 0.48 & 0.54 & -49.9 \\
\hline 401 & 58 & 23080 & 51.3 & 5.0 & 24442 & 1157 & 2095 & 2299 & 0.49 & 0.57 & -19.5 \\
\hline 400 & 61 & 24446 & 56.9 & 5.0 & 25784 & 1258 & 2071 & 2253 & 0.50 & 0.57 & -21 \\
\hline 401 & 65 & 26159 & 62.6 & 7.5 & 26867 & 1405 & 2044 & 2289 & 0.52 & 0.60 & -11.4 \\
\hline 399 & 74 & 29377 & 68.4 & 7.5 & 30743 & 1538 & 2065 & 2292 & 0.51 & 0.59 & -11.7 \\
\hline 402 & 80 & 32144 & 74.3 & 7.5 & 33446 & 1688 & 2103 & 2315 & 0.52 & 0.60 & -12.4 \\
\hline 402 & 89 & 35653 & 80.3 & 7.5 & 36971 & 1815 & 2106 & 2303 & 0.51 & 0.57 & -12.8 \\
\hline 402 & 99 & 39697 & 86.4 & 7.5 & 41050 & 2031 & 2204 & 2395 & 0.53 & 0.60 & -13 \\
\hline 501 & 20 & 9912 & 20.0 & 2.5 & 10641 & 470 & 2131 & 2398 & 0.46 & 0.56 & -19.2 \\
\hline 499 & 25 & 12517 & 24.9 & 2.5 & 13462 & 601 & 2233 & 2457 & 0.49 & 0.58 & -24 \\
\hline 499 & 31 & 15382 & 30.0 & 2.5 & 16476 & 743 & 2330 & 2524 & 0.51 & 0.60 & -31.7 \\
\hline 499 & 36 & 17950 & 35.2 & 5.0 & 19078 & 875 & 2220 & 2536 & 0.50 & 0.61 & -14 \\
\hline 500 & 37 & 18293 & 35.2 & 5.0 & 19483 & 907 & 2301 & 2628 & 0.53 & 0.64 & -13.8 \\
\hline 502 & 37 & 18570 & 35.2 & 2.5 & 19765 & 902 & 2442 & 2615 & 0.55 & 0.62 & -42.4 \\
\hline 501 & 42 & 21092 & 40.4 & 5.0 & 22304 & 989 & 2220 & 2494 & 0.48 & 0.57 & -16.8 \\
\hline 501 & 43 & 21497 & 40.4 & 5.0 & 22709 & 1062 & 2382 & 2676 & 0.55 & 0.65 & -14.5 \\
\hline 500 & 44 & 22218 & 40.4 & 2.5 & 23323 & 1016 & 2412 & 2561 & 0.52 & 0.57 & -42.2 \\
\hline 502 & 45 & 22649 & 40.4 & 2.5 & 23942 & 1062 & 2521 & 2677 & 0.55 & 0.62 & -49 \\
\hline 500 & 50 & 25030 & 45.8 & 5.0 & 26341 & 1170 & 2346 & 2602 & 0.51 & 0.60 & -17.5 \\
\hline 501 & 51 & 25601 & 45.8 & 2.5 & 26742 & 1166 & 2460 & 2595 & 0.53 & 0.58 & -50.9 \\
\hline 504 & 59 & 29757 & 51.3 & 2.5 & 30932 & 1346 & 2550 & 2674 & 0.54 & 0.59 & -53.1 \\
\hline 499 & 60 & 30064 & 51.3 & 5.0 & 31435 & 1358 & 2459 & 2698 & 0.52 & 0.60 & -19.7 \\
\hline 500 & 65 & 32269 & 56.9 & 5.0 & 33631 & 1474 & 2428 & 2641 & 0.52 & 0.59 & -21.2 \\
\hline 499 & 66 & 33154 & 62.6 & 7.5 & 33898 & 1617 & 2352 & 2633 & 0.55 & 0.63 & -10.9 \\
\hline 497 & 76 & 37646 & 68.4 & 7.5 & 39028 & 1776 & 2385 & 2647 & 0.53 & 0.61 & -11.7 \\
\hline 500 & 81 & 40484 & 74.3 & 7.5 & 41806 & 1930 & 2405 & 2648 & 0.54 & 0.62 & -12.4 \\
\hline 499 & 90 & 44737 & 80.3 & 7.5 & 46074 & 2081 & 2415 & 2641 & 0.54 & 0.60 & -12.8 \\
\hline 500 & 100 & 50120 & 86.4 & 7.5 & 51483 & 2330 & 2528 & 2747 & 0.56 & 0.63 & -13.1 \\
\hline 500 & 100 & 50120 & 86.4 & 7.5 & 51483 & 2314 & 2511 & 2728 & 0.55 & 0.62 & -13.1 \\
\hline 601 & 15 & 8956 & 15.1 & 5.0 & 10022 & 371 & 1881 & 2504 & 0.34 & 0.51 & -11.6 \\
\hline 599 & 20 & 12108 & 20.0 & 5.0 & 13190 & 518 & 2113 & 2642 & 0.41 & 0.55 & -13.6 \\
\hline 598 & 25 & 15075 & 24.9 & 5.0 & 16174 & 657 & 2237 & 2686 & 0.45 & 0.57 & -14.4 \\
\hline 599 & 30 & 17964 & 30.0 & 5.0 & 19080 & 806 & 2347 & 2738 & 0.49 & 0.60 & -14.6 \\
\hline 602 & 35 & 21056 & 35.2 & 5.0 & 22191 & 945 & 2400 & 2741 & 0.50 & 0.60 & -15.4 \\
\hline 600 & 40 & 24256 & 40.4 & 5.0 & 25408 & 1090 & 2446 & 2748 & 0.51 & 0.61 & -15.7 \\
\hline 600 & 46 & 27637 & 45.8 & 5.0 & 28801 & 1265 & 2538 & 2815 & 0.55 & 0.63 & -16.5 \\
\hline 600 & 52 & 31119 & 51.3 & 5.0 & 32295 & 1398 & 2532 & 2778 & 0.54 & 0.61 & -17.2 \\
\hline 599 & 58 & 34431 & 56.9 & 7.5 & 35626 & 1565 & 2477 & 2804 & 0.53 & 0.62 & -10.2 \\
\hline 599 & 64 & 38415 & 62.6 & 7.5 & 39625 & 1735 & 2523 & 2826 & 0.54 & 0.63 & -10.7 \\
\hline 601 & 71 & 42777 & 68.4 & 7.5 & 43996 & 1923 & 2583 & 2866 & 0.55 & 0.63 & -11.2 \\
\hline 600 & 79 & 47468 & 74.3 & 7.5 & 48699 & 2121 & 2642 & 2909 & 0.56 & 0.64 & -11.7 \\
\hline 600 & 88 & 52680 & 80.3 & 7.5 & 53923 & 2314 & 2685 & 2936 & 0.57 & 0.63 & -12.2 \\
\hline 602 & 97 & 58594 & 86.4 & 7.5 & 59792 & 2524 & 2738 & 2976 & 0.57 & 0.63 & -12.7 \\
\hline 600 & 98 & 58500 & 86.4 & 7.5 & 59755 & 2540 & 2756 & 2995 & 0.57 & 0.64 & -12.7 \\
\hline 599 & 108 & 64915 & 92.7 & 10.0 & 66127 & 2778 & 2758 & 3055 & 0.57 & 0.64 & -13.6 \\
\hline 651 & 15 & 9706 & 15.1 & 5.0 & 10599 & 398 & 2017 & 2684 & 0.37 & 0.54 & -13.3 \\
\hline 650 & 20 & 13006 & 20.0 & 5.0 & 13920 & 541 & 2208 & 2761 & 0.42 & 0.56 & -13.4 \\
\hline 651 & 25 & 16022 & 24.9 & 5.0 & 16953 & 688 & 2343 & 2813 & 0.47 & 0.59 & -13.7 \\
\hline 652 & 29 & 19157 & 30.0 & 5.0 & 20115 & 834 & 2429 & 2834 & 0.49 & 0.60 & -14.2 \\
\hline 650 & 35 & 22562 & 35.2 & 5.0 & 23541 & 969 & 2459 & 2809 & 0.50 & 0.59 & -14.8 \\
\hline 650 & 41 & 26370 & 40.4 & 5.0 & 27368 & 1129 & 2534 & 2847 & 0.51 & 0.60 & -15.2 \\
\hline 651 & 47 & 30811 & 45.8 & 5.0 & 31826 & 1288 & 2584 & 2866 & 0.51 & 0.59 & -16.4 \\
\hline 651 & 53 & 34151 & 51.3 & 7.5 & 35231 & 1458 & 2527 & 2897 & 0.51 & 0.61 & -9.7 \\
\hline 650 & 58 & 37878 & 56.9 & 7.5 & 38982 & 1621 & 2565 & 2904 & 0.52 & 0.61 & -10.1 \\
\hline 650 & 65 & 42088 & 62.6 & 7.5 & 43213 & 1791 & 2605 & 2917 & 0.53 & 0.61 & -10.6 \\
\hline 649 & 72 & 46915 & 68.4 & 7.5 & 48058 & 1983 & 2664 & 2956 & 0.54 & 0.61 & -11.2 \\
\hline 649 & 80 & 51644 & 74.3 & 7.5 & 52840 & 2184 & 2722 & 2996 & 0.55 & 0.62 & -11.6 \\
\hline 649 & 88 & 57242 & 80.3 & 7.5 & 58454 & 2409 & 2796 & 3057 & 0.57 & 0.63 & -12.1 \\
\hline 649 & 99 & 63956 & 86.4 & 7.5 & 65182 & 2661 & 2888 & 3138 & 0.58 & 0.64 & -12.8 \\
\hline 649 & 111 & 71963 & 92.7 & 10.0 & 73201 & 2950 & 2929 & 3245 & 0.58 & 0.65 & -13.9 \\
\hline
\end{tabular}


Public reporting burden for this collection of information is estimated to average 1 hour per response, including the time for reviewing instructions, searching existing data sources, gathering and maintaining the data needed, and completing and reviewing the collection of information. Send comments regarding this burden estimate or any other aspect of this collection of information, including suggestions for reducing this burden, to Washington Headquarters Services, Directorate for Information Operations and Reports, 1215 Jefferson Davis Highway, Suite 1204, Arlington, VA 22202-4302, and to the Office of Management and Budget, Paperwork Reduction Project (0704-0188), Washington, DC 20503.
1. AGENCY USE ONLY (Leave blank)
2. REPORT DATE 3. REPORT TYPE AND DATES COVERED
September 2002
Technical Memorandum

4. TITLE AND SUBTITLE

Laboratory Model $50 \mathrm{~kW}$ Hall Thruster

6. $\operatorname{AUTHOR}(\mathrm{S})$

WU-755-B4-05-00

David Manzella, Robert Jankovsky, and Richard Hofer

7. PERFORMING ORGANIZATION NAME(S) AND ADDRESS(ES)

National Aeronautics and Space Administration

John H. Glenn Research Center at Lewis Field

Cleveland, Ohio 44135-3191

5. FUNDING NUMBERS

9. SPONSORING/MONITORING AGENCY NAME(S) AND ADDRESS(ES)

National Aeronautics and Space Administration

Washington, DC 20546-0001

8. PERFORMING ORGANIZATION REPORT NUMBER

E-13569

11. SUPPLEMENTARY NOTES

Prepared for the 38th Joint Propulsion Conference and Exhibit, cosponsored by the AIAA, ASME, SAE, and ASEE, Indianapolis, Indiana, July 7-10, 2002. David Manzella, The University of Toledo, 2801 W. Bancroft Street, Toledo, Ohio 43606; Robert Jankovsky, NASA Glenn Research Center; and Richard Hofer, QSS Group, Inc., Cleveland, Ohio 44135. Responsible person, David Manzella, organization code 5430, 216-977-7432.

\section{2a. DISTRIBUTION/AVAILABILITY STATEMENT}

Unclassified - Unlimited

Subject Category: 16 12b. DISTRIBUTION CODE

Available electronically at http://gltrs.grc.nasa.gov

This publication is available from the NASA Center for AeroSpace Information, 301-621-0390.

13. ABSTRACT (Maximum 200 words)

A 0.46 meter diameter Hall thruster was fabricated and performance tested at powers up to 72 kilowatts. Thrusts up to 2.9 Newtons were measured. Discharge specific impulses ranged from 1750 to 3250 seconds with discharge efficiencies between 46 and 65 percent. Overall specific impulses ranged from 1550 to 3050 seconds with overall efficiencies between 40 and 57 percent. Performance data indicated significant fraction of multiple-charged ions during operation at elevated power levels. Cathode mass flow rate was shown to be a significant parameter with regard to thruster efficiency.

\section{SUBJECT TERMS}

Electric propulsion; Hall thruster

\begin{tabular}{|c|c|}
\hline $\begin{array}{c}\text { 17. SECURITY CLASSIFICATION } \\
\text { OF REPORT } \\
\text { Unclassified }\end{array}$ & $\begin{array}{c}\text { 18. SECURITY CLASSIFICATION } \\
\text { OF THIS PAGE } \\
\text { Unclassified }\end{array}$ \\
\hline
\end{tabular}

NSN 7540-01-280-5500

19. SECURITY CLASSIFICATION
OF ABSTRACT
Unclassified

Unclassified
NASA TM-2002-211887

AIAA-2002-3676 